\title{
Effect of late-season nitrogen fertilization on grain yield and on flour rheological quality and stability in common wheat, under different production situations
}

\author{
Massimo Blandino, Federico Marinaccio, Amedeo Reyneri \\ Department of Agricultural, Forest and Food Sciences, University of Torino, Grugliasco (TO), Italy
}

\begin{abstract}
The increasing demand for a high and homogeneous technological quality of common wheat (Triticum aestivum L.) points out the necessity of improving wheat with by a higher protein (GPC) and gluten content, strength of dough (W) and dough stability. Among the current crop practices, late-season nitrogen $(\mathrm{N})$ fertilization, from heading to flowering, is generally considered the practice that has the most effects on the storage proteins and technological quality of the grain. In order to explore the influence late-season $\mathrm{N}$ application can have on the dough properties and on the formation of homogeneous lots in more detail, a research was set up between 2007 and 2013, over 6 growing seasons at different sites in North West Italy using the Bologna cultivar in each of the trials. Three different late-season $\mathrm{N}$ fertilization strategies were compared: T1, control without a late distribution of N; T2, foliar N fertilization at flowering; T3, top-dress granular soil fertilization at the beginning of heading. A randomized complete block experimental design with four replicates was adopted. The grain
\end{abstract}

Correspondence: Amedeo Reyneri, Department of Agricultural, Forest and Food Sciences, University of Torino, Largo Paolo Braccini 2, 10095 Grugliasco (T0), Italy.

Tel.: +39.011.6708778 - Fax. +39.011.6708798.

E-mail: amedeo.reyneri@unito.it

Key words: Triticum aestivum; alveograph; grain quality; Mixolab ${ }^{\circledR}$.

Acknowledgements: the authors would like to thank Fabio Carnaroglio, Mattia Ciro Mancini, Alessandro Peila and Valentina Sovrani for their precious help and cooperation in the laboratory and field work. The research was conducted with the financial support of the Regione Piemonte, as part of the QUALICHAIN project.

Conference presentation: SIA XLIV Congress, Bologna, 2015.

Received for publication: 18 January 2016.

Revision received: 17 March 2016.

Accepted for publication: 18 March 2016.

(C) Copyright M. Blandino et al., 2016

Licensee PAGEPress, Italy

Italian Journal of Agronomy 2016; 11:745

doi:10.4081/ija.2016.745

This article is distributed under the terms of the Creative Commons Attribution Noncommercial License (by-nc 4.0) which permits any noncommercial use, distribution, and reproduction in any medium, provided the original author(s) and source are credited. yield, GPC, W and P/L indexes were analyzed. Moreover, the rheological and enzymatic properties of the samples were studied using a Mixolab ${ }^{\circledR}$ analyser (Chòpin Technologies, Paris, France).

Grain yield was found to be unaffected by the fertilization treatments, while the late $\mathrm{N}$ application (T2, T3) significantly increased GPC. Only the granular $\mathrm{N}$ fertilization (T3) increased the W index compared to T1, while the P/L index was not affected by any of the fertilization strategies. Furthermore, the T3 strategy was always more effective in reducing the variability of the $\mathrm{W}$ index than the T2 and the T1 strategies. Water absorption and dough development time were higher in T3, than in T1, while intermediate results were reached for T2. The effect of late-season $\mathrm{N}$ fertilization was also significant on the starch behaviour of the dough, as an increase in starch gelatinization and retrogradation was observed. In short, the top-dress granular $\mathrm{N}$ fertilizer applied at the beginning of heading (T3) led to a more constant increase in GPC and flour rheological quality than the foliar application. Moreover, the adoption of this fertilization strategy resulted in a reduction in qualitative variability under different environmental and soil conditions.

\section{Introduction}

Currently, the increasing demand for specific quality wheat by the milling sector and the food industry points out the necessity of obtaining wheat lots with high and homogeneous technological quality.

Among the various wheat categories, the demand for the excel grade is increasing. Baking products of superior quality require standardized improver wheat flour characterized by high protein (GPC) and gluten contents, strength of dough (W) and dough stability (Foca et al., 2007). In South Europe, superior quality common wheat (Triticum aestivum L.) flour is mainly obtained by adopting detailed crop practices, since the various pedo-climatic conditions can influence the growth of plants in an irregular way and thus lead to a variable response in the formation and accumulation of the reserves in kernels (Dupont and Altenbach, 2003; Saint Pierre et al., 2008; Troccoli et al., 2000).

Nitrogen $(\mathrm{N})$ fertilization is the main crop practice that can influence the storage proteins and rheological properties of flour (Flagella, 2006; Fuertes-Mendizábal et al., 2010). The rate and timing of $\mathrm{N}$ applications are crucial factors, not only to obtain high yields, but also to increase GPC, gluten and the rheological parameters (Borghi et al., 1997; Garrido-Lestache et al., 2005; Corbellini et al., 2006). Generally, in Southern European climatic conditions, the application of $\mathrm{N}$ fertilizer is split into two distributions: a first granular $\mathrm{N}$ fertilization is applied at tillering [growing stage (GS) 20] (Zadoks et al., 1974) and a second one at the beginning of stem elongation (GS 31)].

However, a third top-dressing or foliar $\mathrm{N}$ application, from the boot stage (GS 40) until the beginning of anthesis (GS 62), could enrich the $\mathrm{N}$ content of the vegetative organs (Oury et al., 2003). As a conse- 
quence, more $\mathrm{N}$ would be available to be translocated later on to the grain, thus leading to an enhancement and stabilization of the GPC and gluten property (Fuertes-Mendizábal et al., 2010).

Another strategy that can be adopted to enhance wheat GPC is to use concentrated foliar sprays between heading and flowering (Fageria $e t$ al., 2009) at a low $\mathrm{N}$ rate in order to limit the risk of foliage burning (Brown and Petrie, 2006). The application of foliar $\mathrm{N}$ fertilizer could easily be applied in mixtures with fungicides to control Fusarium head blight, thus minimizing the cost of its distribution.

The determination of the rheological properties of wheat flour dough is essential. The most common tests are empirical and are based on instruments such as the farinograph and alveograph (Ktenioudaki $e t$ al., 2010). Recently, a new rheological tool has been introduced, Mixolab $^{\circledR}$ (Chòpin Technologies, Paris, France); this instrument, through just one test, can provide information on the rheological properties during kneading, as well as on the protein quality, starch properties and enzymatic activity, and can thus reduce the testing labor requirements and enhance information on baking behaviour (Codin et al., 2012).

In order to satisfy the demand for common wheat for superior quality flour, it is necessary to explore the effect of the late-season $\mathrm{N}$ application on the dough properties in more detail. Moreover, in order to guarantee the formation of more homogeneous lots, in term of qualitative traits, to comply with the increasing requirements of the food chains, there is also a need to verify the role of these fertilization practices on reducing the variability of the growing conditions in different production situations.

Therefore, the aim of this study was to evaluate the effect of late-season $\mathrm{N}$ fertilization strategies, by comparing a granular $\mathrm{N}$ distribution with a foliar N application, on winter wheat yield, GPC and rheological quality stabilization, evaluated using the Mixolab ${ }^{\circledR}$ instrument (Chòpin Technologies), under different production situations.

\section{Materials and methods}

The experiment was set up between 2007 and 2013, over 6 growing season at different sites in North West Italy that are representative of the main winter cereal cropping areas. A total of 18 trials (6 growing seasons X 3 sites) were performed. The main soil properties and meteorological information pertaining to the experimental fields are summarized in Table 1.

Three different late-season $\mathrm{N}$ fertilization strategies were compared in order to establish the influence on wheat quality: i) T1, control without $\mathrm{N}$ distribution after the stem elongation stage (GS 31); ii) T2, foliar $\mathrm{N}$ fertilization at flowering (GS 65): $5 \mathrm{~kg} \mathrm{~N} \mathrm{ha}^{-1}$ was applied using a foliar liquid fertilizer; iii) T3, top-dress granular soil fertilization at the beginning of heading (GS 52): $40 \mathrm{~kg} \mathrm{~N} \mathrm{ha}^{-1}$ was applied, top-dressed, as ammonium nitrate $(27 \% \mathrm{~N} \mathrm{w} / \mathrm{w})$.

All the plots received $130 \mathrm{~kg} \mathrm{~N}^{-1}$ split into $50 \mathrm{~kg} \mathrm{~N}^{-1}$ at the tillering stage (GS 25) and $80 \mathrm{~kg} \mathrm{~N} \mathrm{ha}^{-1}$ at stem elongation (GS 31) as ammonium nitrate (N 27\%; Yara S.p.A., Milan, Italy).

The foliar liquid fertilizer used in T2 was YaraVitaTM Last@ N (Yara Italia S.p.A.) and had a composition of $312 \mathrm{~g} \mathrm{~N} \mathrm{~L}^{-1}, 25 \%$, of which 3.9, 3.9 and $10.6 \%$ were nitrate, ammonium and ureic $\mathrm{N}$, respectively; $16 \mathrm{~L}$ of product formulation $\mathrm{ha}^{-1}$, according to the commercially recommended rate).

The complete treatment schedule is summarized in Table 2.

The experimental design was a randomized complete block with four replicates. The plot size was $7 \times 1.5 \mathrm{~m}$. All the trials were performed using the Bologna c.v. (Società Italiana Sementi, San Lazzaro di Savena, B0, Italy), a medium-long cycle winter wheat of medium height, currently grown for improver and superior bread making wheat chains.

Table 1. Main pedological (soil was sampled to a depth of 0-30 cm) and meteorological information on the experiment conducted in 18 experimental fields in the $2007-2013$ period in North-West Italy.

\begin{tabular}{|c|c|c|c|c|c|c|}
\hline Growing season & Site & $\begin{array}{l}\text { Soil } \\
\text { texture* }\end{array}$ & $\begin{array}{c}\text { Organic matter } \\
(\%)\end{array}$ & $\begin{array}{c}\text { Total N } \\
\text { content }^{\circ}(\%)\end{array}$ & $\begin{array}{c}\text { Rainfall } \\
\text { (mm) } \\
\text { November-June }\end{array}$ & $\begin{array}{c}\mathrm{GDD}^{\#} \\
\left({ }^{\circ} \mathrm{C} \mathrm{d}^{-1}\right) \\
\text { November-June }\end{array}$ \\
\hline 2007-08 & $\begin{array}{l}\text { Cigliano (VC) } \\
\text { Quargnento (AL) } \\
\text { Riva presso Chieri (TO) }\end{array}$ & $\begin{array}{l}\text { Sandy-Loam } \\
\text { Silty-Loam } \\
\text { Silty-Clayey-Loam }\end{array}$ & $\begin{array}{l}1.7 \\
1.3 \\
1.1\end{array}$ & $\begin{array}{l}0.108 \\
0.060 \\
0.069\end{array}$ & $\begin{array}{l}640 \\
532 \\
604\end{array}$ & $\begin{array}{l}2534 \\
2257 \\
2328\end{array}$ \\
\hline 2008-09 & $\begin{array}{l}\text { Cigliano (VC) } \\
\text { Poirino (TO) } \\
\text { Quargnento (AL) }\end{array}$ & $\begin{array}{l}\text { Sandy-Loam } \\
\text { Silty-Clayey-Loam } \\
\text { Silty-Loam }\end{array}$ & $\begin{array}{l}1.6 \\
1.7 \\
1.1\end{array}$ & $\begin{array}{l}0.077 \\
0.078 \\
0.092\end{array}$ & $\begin{array}{l}1134 \\
859 \\
665\end{array}$ & $\begin{array}{l}2567 \\
2433 \\
2327\end{array}$ \\
\hline 2009-10 & $\begin{array}{l}\text { Cigliano (VC) } \\
\text { Poirino (TO) } \\
\text { Quargnento (AL) }\end{array}$ & $\begin{array}{l}\text { Sandy-Loam } \\
\text { Silty-Clayey-Loam } \\
\text { Silty-Loam }\end{array}$ & $\begin{array}{l}1.5 \\
1.4 \\
1.1\end{array}$ & $\begin{array}{l}0.080 \\
0.078 \\
0.076\end{array}$ & $\begin{array}{l}725 \\
600 \\
503\end{array}$ & $\begin{array}{l}2305 \\
2149 \\
2105\end{array}$ \\
\hline 2010-11 & $\begin{array}{l}\text { Cigliano (VC) } \\
\text { Poirino (TO) } \\
\text { San Pietro Gallo (CN) }\end{array}$ & $\begin{array}{l}\text { Sandy-Loam } \\
\text { Silty-Clayey-Loam } \\
\text { Loam }\end{array}$ & $\begin{array}{l}1.8 \\
1.3 \\
1.9\end{array}$ & $\begin{array}{l}0.103 \\
0.070 \\
0.133\end{array}$ & $\begin{array}{l}831 \\
900 \\
724 \\
\end{array}$ & $\begin{array}{l}2538 \\
2419 \\
2251 \\
\end{array}$ \\
\hline 2011-12 & $\begin{array}{l}\text { Caraglio (CN) } \\
\text { Cigliano (VC) } \\
\text { Poirino (TO) }\end{array}$ & $\begin{array}{l}\text { Loam } \\
\text { Sandy-Loam } \\
\text { Silty-Clayey-Loam }\end{array}$ & $\begin{array}{l}2.5 \\
1.7 \\
1.4\end{array}$ & $\begin{array}{l}0.168 \\
0.124 \\
0.084\end{array}$ & $\begin{array}{l}583 \\
689 \\
572\end{array}$ & $\begin{array}{l}2458 \\
2592 \\
2717\end{array}$ \\
\hline 2012-13 & $\begin{array}{l}\text { Cigliano (VC) } \\
\text { Poirino (TO) } \\
\text { San Pietro Gallo (CN) }\end{array}$ & $\begin{array}{l}\text { Sandy-Loam } \\
\text { Silty-Clayey-Loam } \\
\text { Loam }\end{array}$ & $\begin{array}{l}1.5 \\
1.4 \\
2.4\end{array}$ & $\begin{array}{l}0.091 \\
0.092 \\
0.127\end{array}$ & $\begin{array}{l}710 \\
573 \\
646\end{array}$ & $\begin{array}{l}2348 \\
2349 \\
2174\end{array}$ \\
\hline
\end{tabular}

*United States Department of Agriculture Soil Taxonomy; ${ }^{\circ}$ itrogen $(\mathrm{N})$ content measured at the beginning of wheat tillering; \#accumulated growing degree days for each month using a $0^{\circ} \mathrm{C}$ base. 
The seed bed was set after ploughing $(30 \mathrm{~cm})$ and harrowing. Planting was conducted in $12 \mathrm{~cm}$ wide rows at a seeding rate of 450 seeds $\mathrm{m}^{-2}$. All the plots were treated with two fungicide applications: a mixture of azoxystrobin and cyproconazole (Amistar Xtra ${ }^{\circledR}$, Syngenta Crop Protection S.p.A., Milan, Italy) applied at $0.2 \mathrm{~kg}+0.08 \mathrm{~kg}$ active ingredient (AI) ha ${ }^{-1}$ at steam elongation (GS 35) to control foliar disease and a mixture of prothioconazole + tebuconazole (Prosaro ${ }^{\circledR}$, Bayer Crop Science S.r.l., Milan, Italy, formulation: emulsifiable concentrate) applied as $0.125 \mathrm{~kg} \mathrm{AI} \mathrm{ha}^{-1}$ at flowering (GS 65) to avoid Fusarium Head Blight infection and protect the flag leaf. The foliar fertilizer and fungicide were applied together using a three-nozzle precision sprayer (T-Jet 110/04) with a fine mist at a slow walk to ensure effective coverage. The delivery pressure at the nozzle was $324 \mathrm{KPa}$.

The grain yields were determined at crop maturity using a Walter Wintersteiger cereal plot combine-harvester. The grain yield results were adjusted to $13 \%$ moisture content.

The harvested grains were mixed accurately and $2 \mathrm{~kg}$ grain samples were taken from each plot for qualitative analyses.

\section{Grain protein analyses}

Grain samples ( $300 \mathrm{~g}$ ) from each plot were milled using a Retsch ZM 200 (Retsch GmbH, Haan, Germany), fitted with a $1 \mathrm{~mm}$ aperture sieve, and the resulting wholemeal was analysed by means of near-infrared reflectance spectroscopy, using a NIRSystems 6500 monochromator (Foss-NIRSystems, Silver Spring, MD, USA). The GPC $(\mathrm{N} \times 5.7$, dry matter basis) was determined according to AACC 39-10 (AACC, 2000).

\section{Rheological quality analysis}

Two kg grain samples were milled in an experimental Bona 4RB mill (Bona, Monza, Italy) after tempering according to their hardness.

The alveographic properties were evaluated using a Chòpin alveograph (Chòpin Technologies), according to ICC Standard Method 121 (ICC, 2010).

The rheological and enzymatic properties of the samples obtained in the 2010-2011, 2011-2012 and 2012-2013 growing seasons, for a total of 9 trials, were studied using a Mixolab ${ }^{\circledR}$ analyzer (Chòpin Technologies), according to ICC Standard Method 121 (ICC, 2010). The instrument allows specific information to be obtained on the behavior of dough constituents (protein and starch) by continuously measuring the torque $(\mathrm{Nm})$ produced by the passage of the dough between two mixing blades, submitted to the dual stress of mixing and temperature changes. The resulting Mixolab ${ }^{\circledR}$ (Chòpin Technologies) curve is separated into five different phases. The key parameters derived from the Mixolab $^{\circledR}$ (Chòpin Technologies) curve are: water absorption (WA, \%), which represents the amount of water that flour can absorb to obtain a requested dough consistency to produce a torque (peak $\mathrm{C} 1$ ) of $1.1 \mathrm{Nm}$
+/- 0.05 at $30^{\circ} \mathrm{C}$; dough development time (DDT, min) - the time required to obtain the maximum torque $(\mathrm{Cl})$ at $30^{\circ} \mathrm{C}$; dough stability (min) - the time during which the upper frame is $>\mathrm{Cl}$; amplitude (Nm) - the width of the curve to $\mathrm{Cl}$ which identifies the elasticity of the dough; protein strength $(\mathrm{C} 2, \mathrm{Nm})$ - the decrease in dough consistency due to shear and temperature stress (from $30^{\circ} \mathrm{C}$ to $60^{\circ} \mathrm{C}$ ); starch gelatinization $(\mathrm{C} 3, \mathrm{Nm})$ - the starch granules absorb water and the further increase in temperature (from $60^{\circ}$ to $90^{\circ} \mathrm{C}$ ) results in an increase in viscosity; hot gel stability $(\mathrm{C} 4, \mathrm{Nm})$ - indicates the hot gel stability connected to the amylase activity (at a constant temperature of $90^{\circ} \mathrm{C}$ ); retrogradation starch $(\mathrm{C} 5 \mathrm{-Nm})$ identifies the starch gelling in the cooling phase (from $90^{\circ}$ to $50^{\circ} \mathrm{C}$ ). Further details on the physical changes that occur during a Mixolab ${ }^{\circledR}$ (Chòpin Technologies) measurement have been reported in Rosell et al. (2007).

\section{Statistical analysis}

The results of the Mixolab ${ }^{\circledR}$ (Chòpin Technologies) analyses are reported as the means of 9 trials and four replicates, while the yield, GPC, W and P/L results are reported as the means of 18 trials and four replicates. All the recorded parameters were analyzed obtained by means of an analysis of variance (ANOVA), according to a completely randomized block design, in which the treatment was the independent variable and the trial was a random factor. The residual normal distribution was verified using the Kolmogorov-Smirnov test, while variance homogeneity was verified using the Levene test. Multiple comparison tests were performed according to the REGW-F test on treatment means.

Correlations between the GPC, flour alveograph parameters (W, P/L) and the Mixolab ${ }^{\circledR}$ (Chòpin Technologies) parameters (WA, DDT, amplitude, stability, C2, C3, C4 and C5 values) were assessed by means of Pearson's test $\left({ }^{*},{ }^{* *}\right.$ levels were considered significant at $\mathrm{P}<0.05$ and $\mathrm{P}<0.01)$.

The SPSS for Windows statistical package, Version 22.0 (SPSS Inc., Chicago, IL, USA), was used for the statistical analysis.

\section{Results}

The six growing seasons differed mainly as far as the total rainfall that occurred in the period between the wheat sowing (November) and the dough stage (June) is concerned (Table 1). The 2008-09 and 201011 growing seasons were characterized by higher rainfall, while $2007-$ 08 and 2011-12 resulted in the lowest total rainfall. The total $\mathrm{N}$ content measured at the beginning of wheat tillering differed from site to site within of each growing seasons, ranging from 0.060 to $0.168 \%$.

The average grain yield, the GPC and the mean alveographic indexes

Table 2. Comparison of field experiment treatments conducted in the 2007-2013 period.

\begin{tabular}{|c|c|c|c|c|}
\hline Treatment & $\begin{array}{l}\text { Tillering } \\
\text { GS\# } 25\end{array}$ & $\begin{array}{l}\text { ess granular applic } \\
\left(\mathrm{kg} \mathrm{N} \mathrm{ha}^{-1}\right) \\
\text { Stem elongation } \\
\text { GS } 32\end{array}$ & $\begin{array}{c}\text { Heading } \\
\text { GS } 52\end{array}$ & $\begin{array}{l}\text { Foliar application } \\
\left(\mathrm{kg} \mathrm{N} \mathrm{ha-1)}^{\circ}\right) \\
\text { Flowering } \\
\text { GS } 65\end{array}$ \\
\hline
\end{tabular}

\begin{tabular}{lllcc} 
T1 & 50 & 80 & - & - \\
T2 & 50 & 80 & - & 5 \\
\hline T3 & 50 & 80 & 40 & 1
\end{tabular}

*Ammonium nitrate as a granular fertilizer (27\%); ${ }^{\circ}$ YaraVitaTM Last ${ }^{\circledR} \mathrm{N}$ (Yara S.p.A., Milano, Italy) foliar nitrogen (N) fertilizer, 312 g N L ${ }^{-1}$ (25\%), with an application rate of 11 I ha ${ }^{-1}$; \#growth stage (Zadocks et al., 1974). T1, control without a late distribution of $\mathrm{N} ; \mathrm{T} 2$, foliar $\mathrm{N}$ fertilization at flowering; $\mathrm{T} 3$, top-dress granular soil fertilization at the beginning of heading 
of each treatment are reported in Table 3 . As far as yield is concerned, the statistical analysis did not show any significant difference between the three strategies of late $\mathrm{N}$ fertilization, while significant differences $(\mathrm{P}<0.001)$ were pointed out for GPC. The top-dress granular N fertilization at the beginning of heading (T3) enhanced GPC more than the foliar application at flowering (T2); the protein content increased by $4.3 \%$ and by $8.5 \%$, respectively, compared to the unfertilized control (T1). Thus, the control (T1) reached the goal of satisfying the request of wheat chains for a GPC of $13.0 \%$ for superior bread making (Foca $e t$ $a l ., 2007$ ) in $60 \%$ of the considered cases, while the target of a GPC of $14 \%$ (requests for improver wheat) was only reached in $25 \%$ of the considered production situations (Figure 1). The first qualitative target was reached in 68 and $95 \%$ of the cases for T2 and T3, respectively, for the late-season $\mathrm{N}$ application strategies while the more demanding level for improver wheat was reached in 40 and $70 \%$ of the considered production situations, respectively.

Only the granular late $\mathrm{N}$ fertilization (T3) significantly increased the dough strength W, compared to the control (T1). A significant $(\mathrm{P}<0.001)$ improvement in the $\mathrm{W}$ values with this fertilization strategy was pointed out by increases of 25 and of $16 \%$, compared to the control (T1) and the foliar N application (T2), respectively. The P/L index was not affected by the late season $\mathrm{N}$ fertilization strategies, thus confirming the prevalent role exerted by the pedo-climatic interactions on the tenacity and elasticity of the dough.

As far as the incidence of success for the wheat chains' request for a greater dough strength $(\mathrm{W})$ is concerned, the late-season $\mathrm{N}$ unfertilized control (T1) satisfied the wheat chains' request for the superior bread making wheat $\left(\geq 250 \mathrm{~J} 10^{-4}\right)$ in $82 \%$ of the cases, while the improver quality request ( $\geq 300 \mathrm{~J} 10^{-4}$ ) was only satisfied in $47 \%$ of the cases. The foliar $\mathrm{N}$ fertilizer application at flowering (T2) reached this target in 90 and $60 \%$ of the production situations, respectively. Conversely, the incidences of success for both of the $\mathrm{W}$ qualitative levels, through the top-dress application of granular $\mathrm{N}$ fertilizer (T3), was reached in $100 \%$ of the cases.

The effect of late-season fertilization strategies on the rheological and enzymatic parameters analyzed by means of the Mixolab ${ }^{\circledR}$ (Chòpin Technologies) instrument are summarized in Table 4. Water absorption, DDT and amplitude values highlighted the higher gluten stretch

Table 3. Effects of late-season $\mathrm{N}$ fertilization on winter wheat grain yield, grain protein content and flour alveograph parameters (W and $\mathrm{P} / \mathrm{L}$ ); field experiments conducted in North West Italy in the 2007-2013 period.

\begin{tabular}{|c|c|c|c|c|c|c|c|c|}
\hline \multirow{2}{*}{$\begin{array}{l}\text { Treatment* } \\
\mathrm{T} 1\end{array}$} & \multicolumn{2}{|c|}{$\begin{array}{c}\text { Grain yield } \\
\left(\mathrm{t} \mathrm{ha}^{-1}\right)\end{array}$} & \multicolumn{2}{|c|}{$\begin{array}{l}\text { GPC } \\
(\%)\end{array}$} & \multicolumn{2}{|c|}{$\begin{array}{c}W \\
\left(\mathrm{Jx} 10 \mathrm{E}^{-4}\right)\end{array}$} & \multicolumn{2}{|c|}{ P/L } \\
\hline & $6.1^{\mathrm{a}}$ & \pm 1.8 & $13.3^{c}$ & \pm 1.2 & $301^{\mathrm{b}}$ & \pm 65.8 & $0.99^{\mathrm{a}}$ & \pm 0.44 \\
\hline $\mathrm{T} 2$ & $6.2^{\mathrm{a}}$ & \pm 1.9 & $13.8^{\mathrm{b}}$ & \pm 1.2 & $326^{\mathrm{b}}$ & \pm 47.5 & $1.01^{\mathrm{a}}$ & \pm 0.41 \\
\hline T3 & $6.2^{\mathrm{a}}$ & \pm 2.0 & $14.4^{\mathrm{a}}$ & \pm 1.0 & $377^{\mathrm{a}}$ & \pm 43.0 & $0.93^{\mathrm{a}}$ & \pm 0.29 \\
\hline $\mathrm{P}(\mathrm{F})$ & \multicolumn{2}{|c|}{0.987} & \multicolumn{2}{|c|}{$<0.001$} & \multicolumn{2}{|c|}{0.001} & \multicolumn{2}{|c|}{0.874} \\
\hline
\end{tabular}

*Treatment: see Table 2. GPC, grain protein content; W and P/L, alveograph parameters; T1, control without a late distribution of N; T2, foliar N fertilization at flowering; T3, top-dress granular soil fertilization at the beginning of heading. ${ }^{\text {-cc}}$ Means followed by different letters are significantly different (the level of significance is shown in the table). The reported values are based on 18 experimental fields and 4 replications \pm standard deviation. The interaction between the treatment and the experiment was never significant.

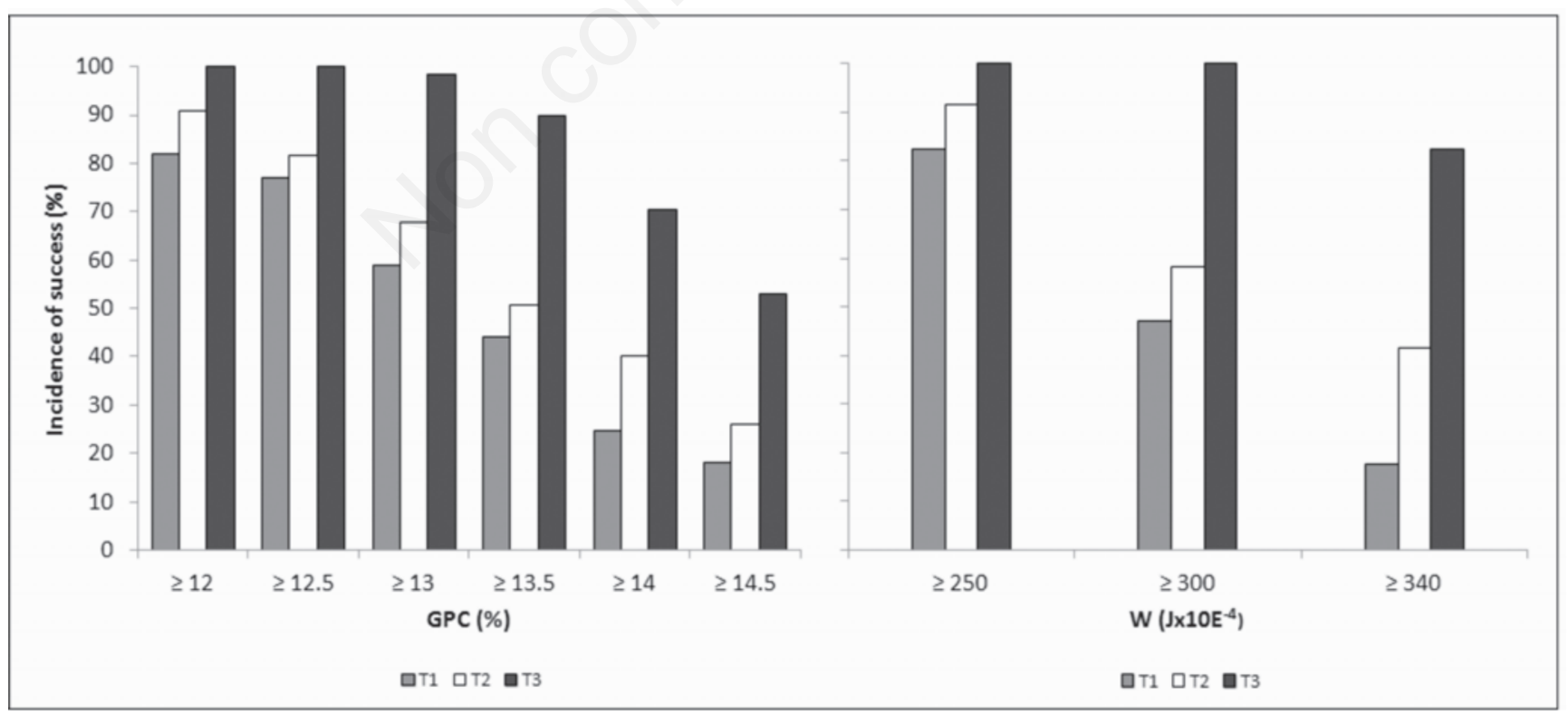

Figure 1. Effects of late-season nitrogen $(\mathrm{N})$ fertilization on the incidence of success of the wheat chains' request for a superior grain protein content (GPC) and dough strength (W); field experiments conducted in North West Italy in the 2007-2013 period for 18 different production situations. T1, control without a late distribution of N; T2, foliar N fertilization at flowering; T3, top-dress granular soil fertilization at the beginning of heading. 
obtained with the application of top-dress granular $\mathrm{N}$ fertilizer at heading (T3), compared to the control (T1). Intermediate results were reached for the foliar application at flowering (T2). The effect of the fertilization strategies was also evident on the starch behaviour of the dough, which is affected by kneading and temperature: after the lateseason $\mathrm{N}$ fertilization, an increase in starch gelatinization (C3) was observed at the onset of the process, together with a higher stability of the hot-formed gel (C4) and a reduction in the starch retrogradation (C5) at the end of the process. The amplitude of the improvement was always more evident for the T3 strategy (5, 9 and $8 \%$, respectively, for the investigated starch parameters) than for T2 (3, 4 and $3 \%$, respectively), compared to the untreated control (T1).

The correlation coefficients between the parameters that describe grain quality are reported in Table 5 . GPC was significantly and positively correlated to the $\mathrm{W}$ alveographic index, as well as to the farinographic one (water absorption, DDT) and the C2 (protein quality) Mixolab $^{\circledR}$ (Chòpin Technologies) parameter. On the other hand, GPC was inversely correlated to $\mathrm{P} / \mathrm{L}$, the amplitude and the Mixolab ${ }^{\circledR}$ (Chòpin Technologies) parameters that describe the starch behaviour (C3, C4 and C5). With the exception of W, no correlations were observed between $\mathrm{P} / \mathrm{L}$ and the other quality parameters.

As far as the environmental effect on qualitative parameters is concerned, the average GPC and W index in the sandy-loam (Cigliano) and in silty-clayey-loam (Poirino) soil were similar; considering the 6 growing seasons the GPC was $13.8 \pm 1.3$ and $13.7 \pm 1.1 \%$, while the $\mathrm{W}$ index

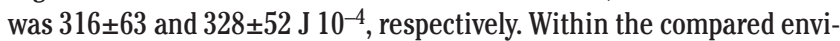
ronments, this variability was positively influenced by the total $\mathrm{N}$ content measured at the beginning of tillering and negatively by the rain- fall during the growing season, while no correlation was found with GDD. Thus, the 2007-08 growing season, with the lowest rainfall, showed the average highest GPC and W index values; conversely the 2008-09, with higher rainfall had the average lowest quality.

As shown in Figure 2, grain yield and the $\mathrm{W}$ index were not clearly correlated for the compared production situations: the late-season $\mathrm{N}$ fertilization strategies enhanced the flour quality at all the productivity levels (from 3 to $9 \mathrm{t} \mathrm{ha}^{-1}$ ). Furthermore, the figure clearly shows that the application of the T3 fertilization strategy reduces the variability of the $\mathrm{W}$ index, considering the different production situations, compared to the untreated control (T1). Although the foliar N fertilization (T2) was able to improve the average $\mathrm{W}$ index, compared to T1, it did not result in a notable reduction in the variation range of this parameter for the considered production situations.

\section{Discussion and conclusions}

The results of this study have pointed out that, for Southern European climatic conditions, a fertilization strategy that involves a late-season $\mathrm{N}$ application, from early heading to flowering, is an essential practice to satisfy the wheat chains' request for superior bread making and improver wheat.

Considering the two late-season $\mathrm{N}$ applications that were compared, it can be seen that although the top-dress granular $\mathrm{N}$ fertilizer applied at heading (T3), did not provide any yield advantages, it did lead to a more constant increase in GPC and flour rheological quality, for differ-

Table 4. Effects of late-season nitrogen fertilization on Mixolab® (Chòpin Technologies) dough development, and on the protein and starch parameters; field experiments conducted in the 2007-2013 period.

\begin{tabular}{|c|c|c|c|c|c|c|c|c|}
\hline Treatment* & $\begin{array}{l}\text { WA } \\
(\%)\end{array}$ & $\begin{array}{l}\text { DDT } \\
(\mathrm{min})\end{array}$ & $\begin{array}{c}\text { Amplitude } \\
\text { (Nm) }\end{array}$ & $\begin{array}{l}\text { Stability } \\
\text { (min) }\end{array}$ & $\begin{array}{c}\text { C2 } \\
(\mathrm{Nm})\end{array}$ & $\begin{array}{c}\text { C3 } \\
(\mathrm{Nm})\end{array}$ & $\begin{array}{c}\mathrm{C} 4 \\
(\mathrm{Nm})\end{array}$ & $\begin{array}{c}\text { C5 } \\
(\mathrm{Nm})\end{array}$ \\
\hline $\mathrm{T} 1$ & $54.0^{c}$ & $3.3^{\mathrm{c}}$ & $0.08^{\mathrm{a}}$ & $10.08^{a}$ & $0.49 c$ & $2.03^{\mathrm{a}}$ & $1.74^{\mathrm{a}}$ & $2.98^{\mathrm{a}}$ \\
\hline $\mathrm{T} 2$ & $55.2^{\mathrm{b}}$ & $4.8^{\mathrm{b}}$ & $0.07^{b}$ & $10.03^{a}$ & $0.52^{\mathrm{b}}$ & $1.98^{\mathrm{ab}}$ & $1.67^{\mathrm{b}}$ & $2.90^{\mathrm{b}}$ \\
\hline T3 & $56.1^{\mathrm{a}}$ & $6.5^{\mathrm{a}}$ & $0.06^{c}$ & $9.96^{\mathrm{a}}$ & $0.55^{\mathrm{a}}$ & $1.92^{b}$ & $1.59 \mathrm{c}$ & $2.71^{\mathrm{c}}$ \\
\hline $\mathrm{P}(\mathrm{F})$ & $<0.001$ & $<0.001$ & $<0.001$ & 0.781 & $<0.001$ & 0.011 & $<0.001$ & $<0.001$ \\
\hline
\end{tabular}

*Ammonium nitrate as a granular fertilizer (27\%). T1, control without a late distribution of N; T2, foliar N fertilization at flowering; T3, top-dress granular soil fertilization at the beginning of heading. Mixolab ${ }^{\circledR}$ (Chòpin Technologies) parameters: WA, water absorption; DDT, dough development time; amplitude, dough elasticity; stability, time of dough stability at constant temperature; C2, protein strength; C3, starch gelatinization; C4, hot gel stability; C5, starch retrogradation. C2, C3, C4 and C5, end points of the corresponding mixing stages. ${ }^{\mathrm{a}-\mathrm{c} M e a n s}$ followed by different letters are significantly different (the level of significance is shown in the table). The reported values are based on 9 experimental fields and 4 replications. The interaction between the treatment and the experiment was never significant.

Table 5. Correlation matrix for the wheat qualitative parameters; field experiments conducted in North West Italy in the 2007-2013 period.

\begin{tabular}{|c|c|c|c|c|c|c|c|c|c|c|}
\hline & GPC & W & P/L & WA & DDT & Amplitude & Stability & C2 & C3 & $\mathrm{C} 4$ \\
\hline W & $0.345^{*}$ & - & - & - & - & - & - & - & - & - \\
\hline $\mathrm{P} / \mathrm{L}$ & $-0.469^{* *}$ & $-0.356^{*}$ & - & - & - & - & - & - & - & - \\
\hline WA & $0.716^{* *}$ & 0.552 & -0.330 & - & - & - & - & - & - & - \\
\hline DDT & $0.568^{* *}$ & $0.724^{* *}$ & -0.358 & $0.658^{* *}$ & - & - & - & - & - & - \\
\hline Amplitude & $-0.263^{*}$ & $-0.774^{* *}$ & 0.127 & $-0.356^{* *}$ & $-0.352 * *$ & - & - & - & - & - \\
\hline Stability & -0.064 & 0.183 & -0.272 & -0.050 & 0.203 & -0.012 & - & - & - & - \\
\hline $\mathrm{C} 2$ & $0.421^{* *}$ & $0.602 *$ & -0.083 & $0.433^{* *}$ & $0.352 * *$ & $-0.418^{* *}$ & $0.445^{* *}$ & - & - & - \\
\hline $\mathrm{C} 3$ & $-0.668^{* *}$ & -0.171 & 0.110 & $-0.454^{* *}$ & $-0.371^{* *}$ & $0.263^{*}$ & $0.380^{* *}$ & -0.088 & - & - \\
\hline $\mathrm{C} 4$ & $-0.634^{* *}$ & -0.216 & 0.349 & $-0.637 * *$ & $-0.530 * *$ & $0.304^{* *}$ & -0.004 & -0.094 & $0.504^{* *}$ & - \\
\hline $\mathrm{C} 5$ & $-0.646^{* *}$ & -0.415 & 0.019 & $-0.499 * *$ & $-0.397^{* *}$ & $0.289 *$ & $0.459^{* *}$ & $-0.260 *$ & $0.878^{* *}$ & $0.471^{* *}$ \\
\hline
\end{tabular}

Qualitative parameters: W and P/L, alveograph parameters; WA, water absorption; DDT, dough development time; amplitude, dough elasticity; stability, time of dough stability at constant temperature; C2, protein strength; $\mathrm{C} 3$, starch gelatinization; $\mathrm{C} 4$, hot gel stability; $\mathrm{C}$, starch retrogradation. *Significance at ${ }^{*} \mathrm{P}<0.05$; and ${ }^{*} \mathrm{P}<0.01$. 
ent production situations and productive yields. This result is in agreement with the work of Jia et al. (1996), who, considering 20 locations in the South of France, demonstrated that a late $\mathrm{N}$ application did not result in a significant increase in winter wheat grain yield but did lead to a clear improvement in GPC and in the bread-making quality properties. Although the foliar $\mathrm{N}$ application at flowering (T2) significantly increased both the GPC and rheological indexes, recorded by means of the Mixolab ${ }^{\circledR}$ (Chòpin Technologies) device, compared to the control (T1), this application strategy showed less capacity to enhance the rheological quality of wheat, by means of a higher protein content, than a granular application at the beginning of heading (T3).

The collected data, which refer to 6 growing seasons and different environments, have highlighted the productive and qualitative variability that can take place in the same wheat cultivar cultivated in different production situations. Within the environments, the variability of qualitative parameters was relevant and mainly influenced by the soil $\mathrm{N}$ content and the rainfall during growing seasons. Furthermore, the range of variability between years was similar among the sites.

The late-season $\mathrm{N}$ fertilization, whether foliar or top-dressed granular, did not affect the productive variability for the different environment and growing seasons, and showed a range of variation that was similar for the treatments. Conversely, it is clear that the late-season $\mathrm{N}$ application strategies, particularly $\mathrm{N}$ granular fertilization at heading, could reduce GPC and the alveograph $\mathrm{W}$ variability for different environments to a great extent, as can be seen in Figure 1. Consequently, this strategy not only increases the probability of satisfying the requests of the quality chains, but it also clearly ensures a more homogeneous quality of raw-material, for the space and temporal variability.

The elastic behaviour of dough (P/L) was more independent of the late-season $\mathrm{N}$ fertilization than W (Fuertes-Mendizábal et al., 2010). The result of the present experimentation, where no differences in $\mathrm{P} / \mathrm{L}$ values were observed for different fertilization strategies, is in agreement with that of the aforementioned authors. However, the data obtained from the Mixolab ${ }^{\circledR}$ (Chòpin Technologies) instrument showed a decrease in dough elasticity (amplitude) for the top-dress granular $\mathrm{N}$ fertilization at heading, and a highly negative correlation between the GPC and P/L values. These results are in agreement with those of Borghi et al. (1995), who described the beneficial effect of increasing the $\mathrm{N}$ rate at heading, not only on the grain protein content but also on dough extensibility (L). Furthermore, the here conducted experiments have confirmed that soil granular $\mathrm{N}$ fertilization, apart from clearly increasing the protein quantity, also increased the protein strength (C2), thus improving its quality (Ozturk et al., 2008). Conversely, all the Mixolab ${ }^{\circledR}$ (Chòpin Technologies) values of the

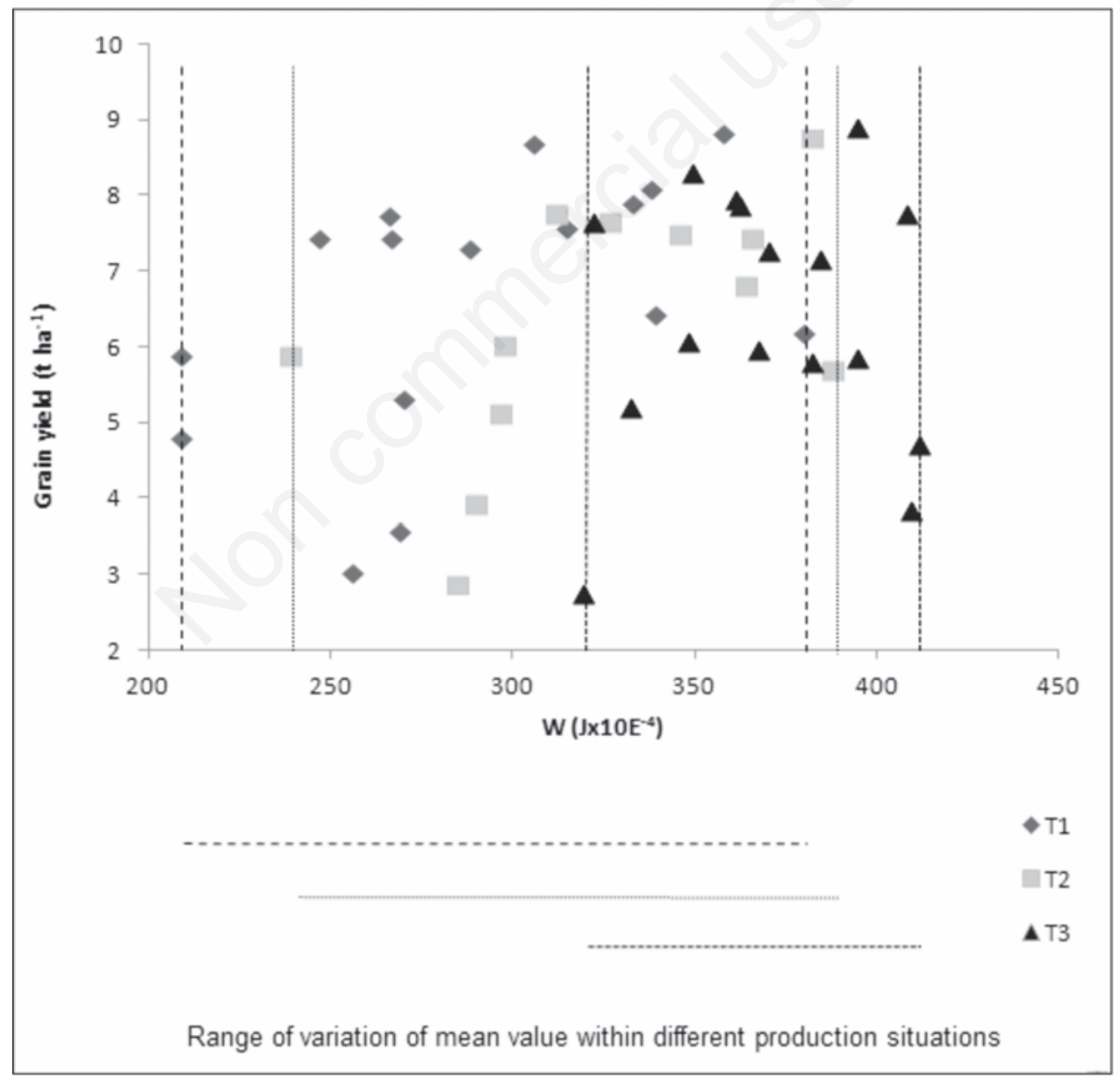

Figure 2. Effects of late-season nitrogen $(\mathrm{N})$ fertilization on yield and dough strength $(\mathrm{W})$ and range of variation of W; field experiments conducted in North West Italy in the 2007-2013 period for 18 different production situations. T1, control without a late distribution of $\mathrm{N}$; T2, foliar $\mathrm{N}$ fertilization at flowering; T3, top-dress granular soil fertilization at the beginning of heading. 
starch parameters (C3, C4 and C5 points) decreased for the late-season $\mathrm{N}$ application and, at the same time, these values were also negatively correlated to the GPC. The observed starch behavior is in agreement with that observed in the study carried by Kahraman et al. (2007), who observed a negative relationship between starch gelling and retrogradation and the protein content in the flour. Koksel et al. (2009) also found a significant negative correlation between the C3, C4 and C5 Mixolab ${ }^{\circledR}$ (Chòpin Technologies) parameters and bread volume.

The foliar $\mathrm{N}$ fertilization at flowering, applied together with a fungicide, at a low $\mathrm{N}$ rate and at a low cost, represents a compromise, since this strategy has been shown to lead to a lower increase in grain protein content and flour rheological quality than the top-dressed granular one at a higher $\mathrm{N}$ rate. Moreover, in the present experiment, the foliar application only contributed minimally to reducing the influence of environmental factors on the qualitative parameters and to promoting the production of more homogeneous raw material.

In conclusion, the best qualitative advantages have been obtained using top-dress soil granular $\mathrm{N}$ fertilization at heading, and the qualitative improvement, which has been constant for different production situations, can thus contribute effectively to the production of more standardized lots in order to obtain superior quality flour.

\section{References}

AACC (American Association of Cereal Chemistry) International, 2000. Approved methods of analysis. 10th. American Association of Cereal Chemistry, St. Paul, MN, USA.

Borghi B, Corbellini M, Minoia C, Palumbo M, Di Fonzo N, Perenzin M, 1997. Effects of Mediterranean climate on wheat bread-making quality. Eur. J. Agron. 6:145-54.

Borghi B, Giordani G, Corbellini M, Vaccino P, Guermandi M, Toderi G, 1995. Influence of crop rotation and fertiliser treatments on wheat bread-making quality. Eur. Food Res. Technol. 4:37-45.

Brown BD, Petrie S, 2006. Irrigated hard winter wheat response to fall, spring, and late season applied nitrogen. Field Crop. Res. 96:260-8.

Codin GG, Mironeasa S, Mironeasa C, Popa CN, Tamba-Berehoiu R, 2012. Wheat flour dough Alveograph characteristics predicted by Mixolab regression models. J. Sci. Food Agric. 92:638-44.

Corbellini M, Perenzin M, Boggini G, Bellocchi G, Scudellari D, Monotti M, 2006. Balance sheet method assessment for nitrogen fertilization in bread wheat: I. Yield and quality. Ital. J. Agron. 3:331-41.

Dupont FM, Altenbach SB, 2003. Molecular and biochemical impacts of environmental factors on wheat grain development and protein synthesis. J. Cereal Sci. 38:133-46.

Fageria NK, Filho MPB, Moreira A, Guimarães CM, 2009. Foliar fertilization of crop plants. J. Plant Nutr. 32:1044-64.
Flagella Z, 2006. Qualità nutrizionale e tecnologica del frumento duro. Ital. J. Agron. 1:203-39.

Foca G, Ulrici A, Corbellini M, Pagani MA, Lucisano M, Franchini GC, Tassi L, 2007. Reproducibility of the Italian ISQ method for quality classification of bread wheats : an evaluation by expert assessors. J. Sci. Food Agric. 87:839-46.

Fuertes-Mendizábal T, Aizpurua A, González-Moro MB, Estavillo JM, 2010. Improving wheat breadmaking quality by splitting the $\mathrm{N}$ fertilizer rate. Eur. J. Agron. 33:52-61.

Garrido-Lestache E, López-Bellido RJ, López-Bellido L, 2005. Durum wheat quality under Mediterranean conditions as affected by $\mathrm{N}$ rate, timing and splitting, $\mathrm{N}$ form and $\mathrm{S}$ fertilization. Eur. J. Agron. 23:265-78.

ICC, 2010. Standard methods of the international association for cereal chemistry 110/1, 105/2, 106/2, 104/1, 173. International Association for Cereal Science and Technology, Vienna, Austria.

Jia Y, Fabre J, Aussenac T, 1996. Effects of growing location on response of protein polymerization to increased nitrogen fertilization for the common wheat cultivar soissons : relationship with some aspects of the breadmaking quality. Cereal Chem. 73:526-32.

Kahraman K, Sakiyan 0, Ozturk S, Koksel H, Sumnu G, Dubat A, 2007. Utilization of Mixolab ${ }^{\circledR}$ to predict the suitability of flours in terms of cake quality. Eur. Food Res. Technol. 227:565-70.

Koksel H, Kahraman K, Sanal T, Ozay DS, Dubat A, 2009. Potential utilization of Mixolab for quality evaluation of bread wheat genotypes. Cereal Chem. 86:522-6.

Ktenioudaki A, Butler F, Gallagher E, 2010. The effect of different mixing processes on dough extensional rheology and baked attributes. J. Sci. Food Agric. 90:2098-104.

Oury FX, Bérad P, Brancourt-Hulmel M, Depatureaux C, Doissinault G, Galic N, Rousset A, Haumez E, Lecomte C, Pluchard P, Rolland B, 2003. Yield and grain protein concentration in bread-making: a review and a study of multi-annual data fom a French breeding program. J. Genet. Breed. 57:59-68.

Ozturk S, Kahraman K, Tiftik B, Koksel H, 2008. Predicting the cookie quality of flours by using Mixolab ${ }^{\circledR}$. Eur. Food Res. Technol. 227:1549-54.

Rosell C, Collar C, Haros M, 2007. Assessment of hydrocolloid effects on the thermo-mechanical properties of wheat using the Mixolab. Food Hydrocoll. 21:452-62.

Saint Pierre C, Petersona CJ, Rossa AS, Ohmac J-B, Verhoevena MC, Larsona M, Hoefera B, 2008. White wheat grain quality changes with genotype, nitrogen fertilization, and water stress. Agron. J. 100:414-20.

Troccoli A, Borrelli GM, De Vita P, Fares C, Di Fonzo N, 2000. Mini review: durum wheat quality: a multidisciplinary concept. J. Cereal Sci. 32:99-113.

Zadoks JC, Chang TT, Konzak CF, 1974. A decimal code for the growth stages of cereals. Weed Res. 14:415-21. 